\title{
副咽頭間隙に発生した傍神経節腫例
}

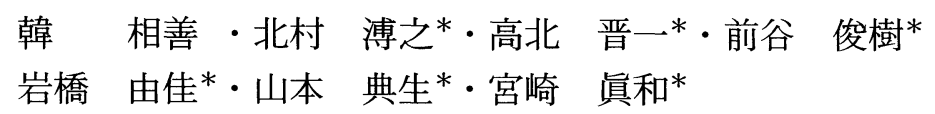

\section{Paraganglioma Arising in the Parapharyngeal Space ; A Case Report}

\author{
Sanson Han \\ (Mitsubishi Kyoto Hospital)
}

\begin{abstract}
Hiroyuki Kitamura, Shin-ichi Takagita, Toshiki Maetani, Yuka Iwahashi, Norio Yamamoto and Masakazu Miyazaki

(Tenri Hospital)
\end{abstract}

Paraganglioma is not a particularly rare type of tumor, but intravagal paraganglioma is very rare. We recently treated a case of intravagal paraganglioma arising in the parapharyngeal space. A 70 year-old male was examined following complaints of infra-auricular swelling. A preoperative carotid angiogram revealed that the tumor had high vascularity and that the carotid bifurcation was not widened. We were able to remove the tumor transcervically with a partial submandibulectomy. Postoperatively, the patient complained only of hoarseness.

Key words : parganglioma, parapharyngeal space, intravagal paraganglioma

はじめに

頭頸部領域に発生する傍神経節腫 (paraganglioma) は 比較的まれな疾患であり，本邦報告例の多くが頸動脈小 体腫瘍や頸静脈鼓室傍神経節腫である. 今回我々は迷走 神経傍神経節腫の 1 例を経験したので若干の文献的考察 を加え報告する.

\section{症 例}

患者：70歳, 男性.

主訴：耳下部腫脹.

既往歴, 家族歴 : 特記すべきことなし.

現病歷：10年前より耳下部腫脹を自覚していたが，平 成 9 年 4 月頃より増大傾向を認めたため同 6 月 18 日天理 よろづ相談所病院耳鼻咽喉科を受診した。
初診時所見(図 1)：左耳下部から顎下部にかけて径 8 $\mathrm{cm}$ 大の弾性軟, 可動性に乏しく, 血管拍動を触知する 腫瘍を認めた。また左咽頭後壁が膨隆し, 左口蓋扁桃は 前方に圧排されていた。な扮脳神経脱落症状は認めなか った。

MRI 所見(図 2)：左副咽頭間陌に $\mathrm{T} 1$ 強調で中信号, $\mathrm{T} 2$ 強調で低〜高信号が混在し，ガドリニウムで不均一 に造影される腫瘍を認めた。耳下腺との連続性はなく, 内頸動脈，外頸動脈を外側に圧排していた。

血管造影所見(図 3 )：外頸動脈末梢に血管増生飞富む 腫瘍を認め, 内頸動脈, 外頸動脈とも外側に圧排偏位し ている. 腫瘍の栄養血管については不明である.

血清生化学, 尿検查も正常で, カテュラミン分画も正 常であった. 


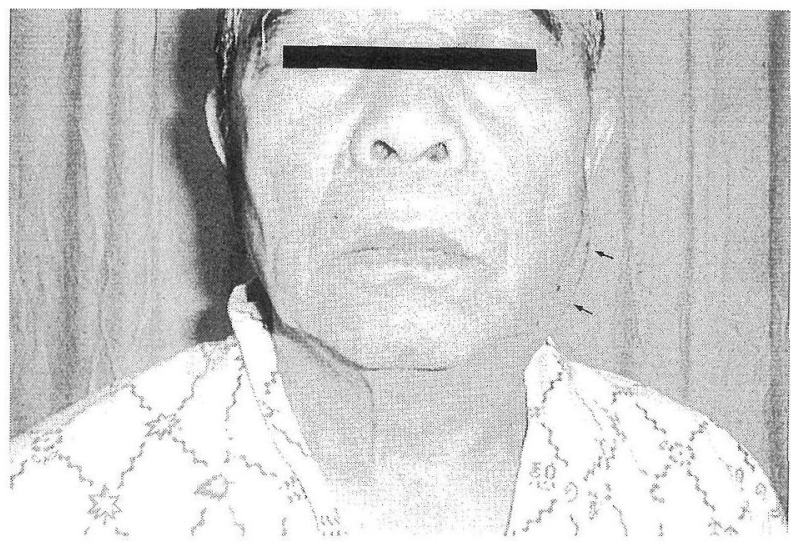

図 1 初診時所見

左耳下部から顎下部にかけての腫脹を認める(矢印).

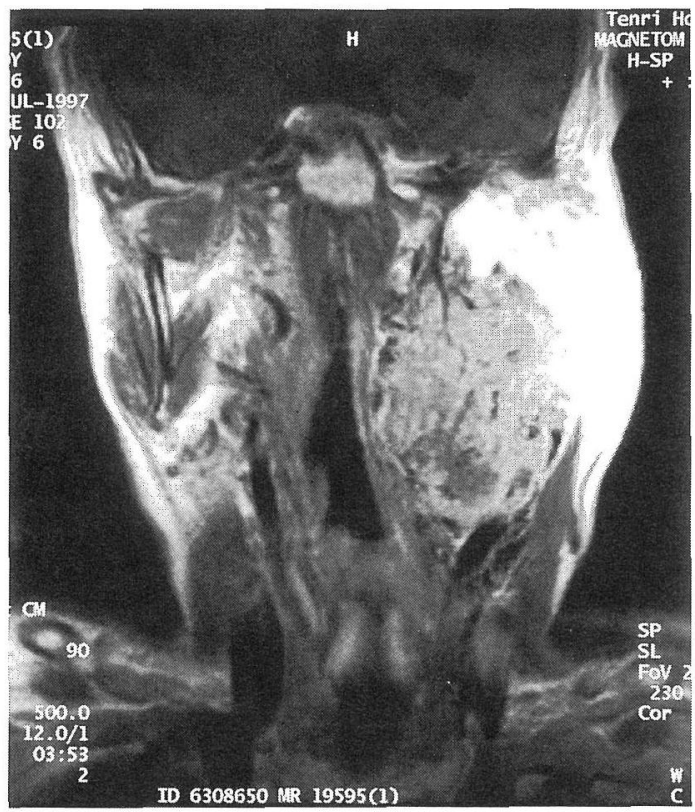

図 2 MRI 所見(冠状断, T1 強調)

副咽頭間隙にガドリニウムで不均一に造影される腫瘍を 認める。

以上の諸検査より頸動脈小体腫瘍を考虑に入れた副咽 頭間隙腫瘍の診断の下に平成 9 年 8 月 21 日手術を施行し た。

手術所見：下顎骨下縁より一横指下でT字切開を行っ た．腫瘍は左外頸動脈からの血流に富み易出血性の腫瘍 であった。頸動脈分岐部直上で腫痬との瘉着が強かった ため, 左外頸動脈を結紮した後腫瘍を周囲から剥離した.

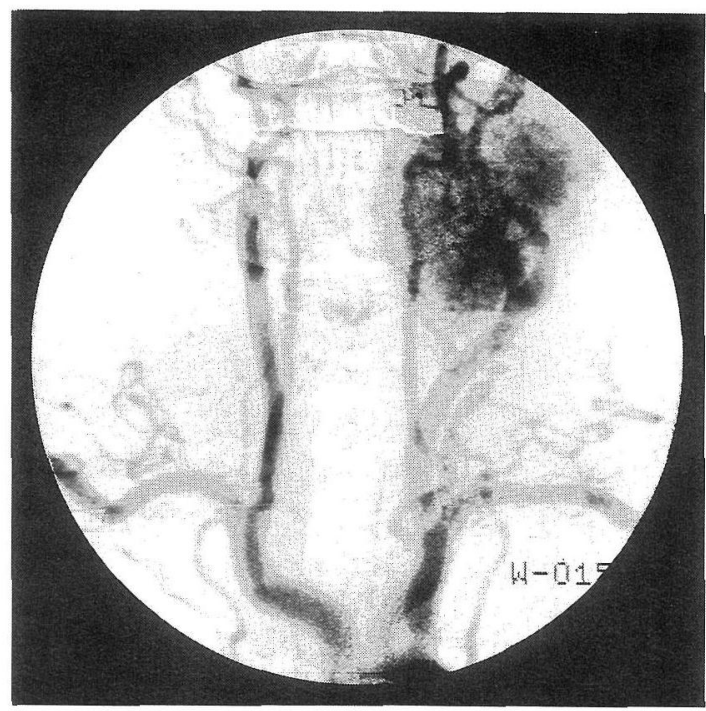

図 3 血管造影所見

血管増生飞富む腫瘍濃染像を認邓, 内・外頸動脈之も外 側に圧排偏位されている。

腫瘍下極は迷走神経に移行し神経本幹は肥厚していた。 腫瘍下極より $6 \mathrm{~cm}$ 下方で肥厚した神経を切断した。舌 下神経は保存して顎二腹筋を切断した後, 下顎角を一部 鉗除して腫瘍上極を確認し，腫瘍を摘出した．術中出血 量は約 $1600 \mathrm{~g}$ であった。

摘出標本（図 4 ）：径 $80 \times 60 \times 30 \mathrm{~mm}$, 表面は暗赤色, 不整であり，内部は不均一充実性で，腫瘍下極から索状 物が連続していた。

病理所見（図 5 )：腫瘍は線維性被膜を有し，内部には

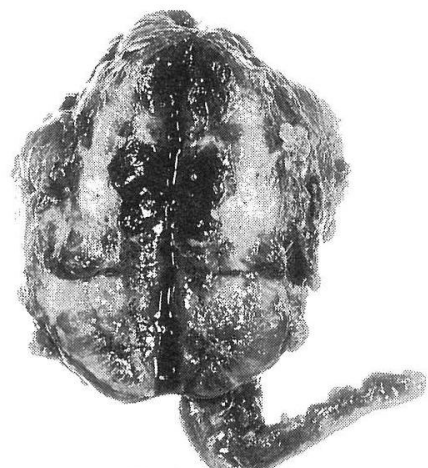

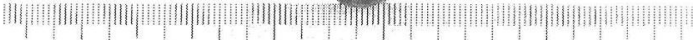

図 4 摘出標本

内部は不均一充実性で, 腫瘍下極から索状物が連続して いる。 


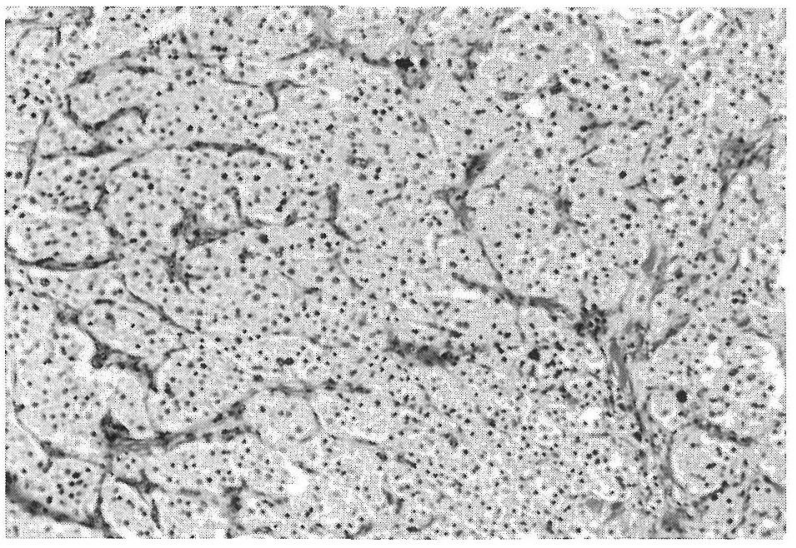

図 5 病理所見 $(\mathrm{HE} \times 40)$ alveolar pattern の細胞増生が認められる.

alveolar patternをとり増生する細胞が認められ, 傍神 経節腫との診断であった。

術後経過: 左反回神経麻痺, 左軟口蓋不全麻痺, 左舌 下神経不全麻痺を認めたが誤嬹はなかった。現在嗄声を 認めるのみで日常生活には支障をきたしていない。

\section{考察}

傍神経節腫は臨床的には発生部位によって傍神経節の 内の舌咽神経と迷走神経の耳介枝から生じる頸静脈鼓室 傍神経節腫, carotid bodyの腫瘍化した頸動脈小体腫瘍,
神経節の直下から発生し頸静脈洞の近くに生じる迷走神 経傍神経節腫に分類される.

Muratori ${ }^{11}$ が1932年ニワトリの迷走神経内に carotid body 類似の細胞が存在することを最初権察し，1935 年 White ${ }^{2)}, 1950$ 年 Sato ら³) がヒトの迷走神経内にも vagal bodyが存在することを発見した。このvagal body から発生する迷走神経傍神経節腫は1935年 Stout ${ }^{4)}$ が報告して以来 100 例以上の報告が認められるが，本邦 では我々の渉猟し得た範团で自験例を含め 14 例(5) 15) と まれな疾患とい兄る。以下本邦報告例の迷走神経傍神経 節腫の臨床像につき検討した(表 1 )。

1) 臨床像：性差は男性：女性 $=5: 9$ 之女性に多く 年齢は22歳から71歳(平均 49.4 歳) で, Lack ら ${ }^{16)}$ の報告 とほぼ一致していた。羅病期間は最短 2 力月, 最長 10 年 で, 自覚症状は頸部腫瘤 9 例, 咽頭側壁腫脹 4 例, 嗄声 4 例, 咳 2 例, 舌運動障害 1 例, 咽頭異常感 1 例, 雚下 困難 1 例であり, 術前に脳神経症状を呈した症例は 8 例 (第X脳神経 7 例, 第XI 脳神経 1 例, 第XII脳神経 2 例) であり, 経過の短い例でも脳神経症状が出現していた。

2 ) 診断：副咽頭間隙の解剖学的特異性から CT, MRI が有効である. 特に MRI は軟部組織の濃度分解 能に優れ，手術の際に問題となる頭蓋底との関係を明瞭 に描出できる。をた傍神経節腫は血管増生に富えだ腫瘍 であるため，頸動脈との位置関係を知るらえでも術前に 血管造影は必須であり，頸動脈分岐部の圧排，拡大像を

表 1 本報報告例5) 15)

\begin{tabular}{|c|c|c|c|c|c|c|c|c|c|c|c|}
\hline & 報告者 & 年 & 性 & 年齢 & 患側, & 最大径 & 羅病期間 & $\begin{array}{l}\text { 術 前 } \\
\text { 脳神経 } \\
\text { 麻 㪏 }\end{array}$ & 手 術 法 & 術後脳神経麻㾝 & 予 \\
\hline 1 & 高橋ら & 1980 & 女 & 49 & 左, & $60 \mathrm{~mm}$ & 3 年 & $\mathrm{X}, \mathrm{XII}$ & 頸部外切開(全摘) & VII, X, X, XI, XII & 再発なし \\
\hline 2 & 栗田ら & 1983 & 女 & 59 & 左, & 不明 & 不明 & 不明 & 下顎骨離断 (全摘) & $\mathbb{X}, \quad \mathrm{X}, \mathrm{XI}, \mathrm{XII}$ & 再発なし \\
\hline 3 & 佐々木ら & 1983 & 女 & 40 & 右, & 不明 & $5 \sim 6$ 年 & $\mathrm{X}$ & 頸部外切開(全摘) & 不明 & 再発なし \\
\hline 4 & 川浦ら & 1984 & 女 & 60 & 右, & 不明 & 4 年 & 不明 & 頸部外切開(全摘) & 不明 & 不明 \\
\hline 5 & 斎藤ら & 1986 & 女 & 27 & 左, & $32 \mathrm{~mm}$ & 2 年 & $\mathrm{X}$ & 頸部外切開(全摘) & $\mathrm{X}$, XII & 頸部リンパ節転移 \\
\hline 6 & 高橋ら & 1987 & 男 & 46 & 右, & 不明 & 不明 & なし & 下顎骨離断 (亜全摘) & VII, $\mathbb{X}, \mathrm{X}$ & 増大なし \\
\hline 7 & 石井ら & 1987 & 女 & 71 & 右, & 不明 & 2 力月 & 不明 & 頸部外切開(亜全摘) & 不明 & 不明 \\
\hline 8 & 多田5 & 1988 & 女 & 57 & 左, & $40 \mathrm{~mm}$ & 1 年 & XII & 頸部外切開(全摘) & $\mathbb{X}, \quad \mathrm{X}, \quad \mathrm{XI}, \quad \mathrm{XII}$ & 再発なし \\
\hline 9 & 菊地ら & 1988 & 女 & 46 & 左, & $60 \mathrm{~mm}$ & 9 年 & $\mathrm{X}$ & 頸部外切開(亜全摘) & $\mathrm{X}, \quad \mathrm{XII}$ & 術後照射, 増大なし \\
\hline 10 & 菊地ら & 1988 & 男 & 38 & 右, & $50 \mathrm{~mm}$ & 2 年 & $\mathrm{X}, \mathrm{XI}$ & 頸部外切開 (亜全摘) & $\mathrm{X}, \mathrm{X}, \mathrm{XI}, \mathrm{XII}$ & 増大なし \\
\hline 11 & 㐘地ら & 1988 & 男 & 36 & 右, & $70 \mathrm{~mm}$ & 9 力月 & $\mathrm{X}$ & 頸部外切開 (全摘) & $\mathbb{X}, \quad \mathrm{X}, \mathrm{XI}, \quad \mathrm{XI}$ & 再発なし \\
\hline 12 & 島田ら & 1994 & 男 & 22 & 右, & 不明 & 10力月 & なし & 頸部外切開 (全摘) & $\mathrm{X}, \mathrm{X}, \quad \mathrm{XII}$ & 再発なし \\
\hline 13 & 木村ら & 1996 & 女 & 71 & 右, & 不明 & 3 年 & なし & 下顎骨離断 (全摘) & X, XII & 再発なし \\
\hline 14 & 自験例 & 1997 & 男 & 70 & 左, & $80 \mathrm{~mm}$ & 10年 & なし & 頸部外切開 (全摘) & $\mathbb{X}, \quad \mathrm{X}, \mathrm{XI}$ & 再発なし \\
\hline
\end{tabular}


認めないことが頸動脈小体腫瘍との鑑別点になる ${ }^{14)}$ と されている.

3 ) 治療：全例外科的摘出が行われているが副咽頭間 隙の解剖学的特性から, 詳細不明例を除き全例術後に X, $\mathrm{X}, \mathrm{XI}$ 脳神経を中心とする脱落症状やホルネル症候が 認められている，経過の長い疾患ではあるが術前より脳 神経脱落症状をきたした症例が 8 例あり，また 1 例に悪 性化 ${ }^{14)}$ を認めていることから放射線治療の有効性が確 認されていない現在ではやはり外科的摘出が第一選択と 考光られる。アプローチとしては腫瘍径が大きい例が多 いため頸部外切開法が妥当であり，本症例のように下顎 角の辺縁切除に上り更に良好な視野が得られ，また必要 に応じて下顎骨離断も考慮すべきであろら。

4 ）予後: 腫瘍の発育は緩慢であり不完全摘出に終わ った 3 例の報告を含め術後の再発, 増大例は報告されて

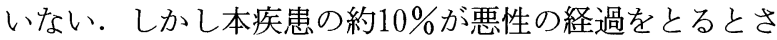
れ ${ }^{14)} ， 1$ 例に頸部リンパ節転移を，また 1 例に悪性化を 認めている. 本症例でも術後 4 力月経過した現在再発は 認められていないが厳重な経過観察が必要と考えられる。

$$
\text { まとめ }
$$

副咽頭間隙に発生した迷走神経傍神経節腫の 1 例を報 告した.

本疾患は病理学的には良性で発育も緩徐であるがリン 公節転移, 遠隔転移を認める例もあり, 治療, 経過観察 は厳重にすべきであると考光られる。

稿を終えるにあたり御校閲を頂きました京都大学大学院医学 研究科 感覚運動系病態学講座 聴覚・言語病態学領域 本庄 䉷教授に深謝致します。

尚, 本論文の要旨は第263回日本耳鼻咽喉科学会大阪地方連 合会(平成 9 年 12 月, 大阪市) そ执いて口演した.

\section{参考文献}

1) Muratori G: Contributo all'innervazione del tessuto paragangliaren annesso del vagoe; all'innervazione del seno carotideo. Anat Anz 75 : 115 123, 1932.
2) White EG : Die Struktur des Glomus caroticum, seine Pathologie und Physiologie und seine Beziehung zum Nervensystem. Beitr Pathol Anat 96 : 177 227, 1935.

3 ) Sato $\mathrm{H}$, Yamamoto $\mathrm{S}$ and Fujii $\mathrm{T}:$ On the paraganglia in the ganglion of the vagus nerve. Tohoku J Exp Med 52 : $39 \sim 42,1950$.

4) Stout AP : The malignant tumors of the peripheral nerves. Am J Cancer 25 : 1 36, 1935.

5 ) 高橋光明, 海野徳二, 林崎勝武, 他 : Vagal Body Tumor の 1 症例. 日耳鼻 $83: 535 \sim 542,1980$.

6 ）栗田宣彦, 小高修二, 真島一彦, 他 : Vagal body origin と思われる chemodectoma の 1 症例. 日耳鼻 $86: 89,1983$.

7 ）佐々木文彦, 古賀佑彦, 竹内 昭, 他: CT 診断が有用で あった vagal body paraganglioma の 1 例. 臨放 $28: 807$ 810, 1983.

8 ）川浦光弘, 大内利昭, 日下田潔, 他 : 副咽頭腔より発生し た Paraganglioma の 1 例. 日耳鼻 $87: 1567,1984$.

9 ) 斎藤裕夫, 小野 勇, 海老原敏, 他 : 頭頸部領域の傍神経 節腫. 耳鼻臨床 $79: 1305 \sim 1318,1986$.

10）高橋光明, 林 浩, 金井直樹, 他 : 副咽頭腔腫瘍の診断 と治療. 耳喉 $59: 617 \sim 623,1987$.

11）石井千佳子, 多田信平：傍咽頭間隙腫瘍 (副神経節腫). 臨 放 $32: 1423 \sim 1425,1987$.

12）多田 渉, 藤原裕美, 河野嘉彦, 他 : 副咽頭間隙に発生し た paraganglioma の一症例. 耳鼻臨床 補27：110～114, 1988.

13）菊地 茂, 喜多村健, 浅井昌大, 他: intravagal paraganglioma の 3 症例. 耳鼻臨床 $81: 1319 \sim 1326,1988$.

14）島田千恵子, 山口展正, 八代利伸, 他 : 副咽頭間隙に生じ た vagal body tumor の 1 症例. 耳展 $37: 212 \sim 218,1994$.

15）木村隆保, 丸山晋, 中井茂, 他 : 迷走神経原性腫瘍 —schwannoma と paraganglioma一. 頭頸部腫瘍 22: 112 $\sim 119,1996$.

16) Lack EE, Cubilla AL, Woodruff JM, et al : Paragangliomas of the head and neck region. Cancer $39: 397 \sim 409$, 1977.

$\left.\begin{array}{l}\text { 原稿受付 : 平成 } 9 \text { 年 } 12 \text { 月 } 12 \text { 日 } \\ \text { 原稿採択 : 平成 } 10 \text { 年 } 1 \text { 月 } 7 \text { 日 } \\ \text { 別刷請求先 : 韓 相善 } \\ \text { † } 615-8552 \text { 京都市西京区桂御所町 } 1 \\ \text { 三菱京都病院耳鼻咽喉科 }\end{array}\right)$

